\title{
EFFECT OF BIOLOGICAL SOIL CRUSTS ON THE SEED GERMINATION OF THREE PLANT SPECIES UNDER LABORATORY CONDITIONS
}

\author{
Marisela Pando-Moreno ${ }^{1,3}$, Víctor Molina ${ }^{1}$, Enrique Jurado ${ }^{1}$ and Joel Flores $^{2}$ \\ 'School of Forestry Sciences, Universidad Autónoma de Nuevo León. Linares, Nuevo León, Mexico \\ ${ }^{2}$ División de Ciencias Ambientales, Instituto Potosino de Investigación Científica y Tecnológica. \\ San Luis Potosí, San Luis Potosí, Mexico \\ ${ }^{3}$ Corresponding author: marisela.pandomr@uanl.edu.mx
}

\begin{abstract}
Semiarid grasslands in northeastern Mexico contain endemic plants and animals, and are an important refuge for resident and migratory animals. Here, as in other semiarid areas, biological soil crusts (BSC) are a key component of the ecosystem. However, findings about their effect on the germination of vascular plants are contradictory. We asked whether seed germination of some native plant species would be inhibited by the presence of BSC as it has been found in other studies; in turn, we evaluated the effect of five lichens (Endocarpon pusillum Hedw., Placidium sp., Psora cerebriformis W.A.Weber, Psora decipiens (Hedw.) Hoffm., Xanthoparmelia chlorochroa (Tuck.) Hale), one cyanobacteria (Nostoc commune Vauch.), and one hepatic (Oxymitra sp.), from the dominant BSC of the area on the germination percentage (germinability) and speed of germination $\left(t_{50}\right)$ of three native plant species: Frankenia gypsophila I.M.Johnst., Muhlenbergia arenicola Buckl., and Sartwellia mexicana A.Gray. Germination tests were carried out in an environmental chamber at $26^{\circ} \mathrm{C}$ and at a constant humidity of $60 \%$ with $12: 12$ hours light and darkness. $\mathrm{BSC}$ did not affect germination percentage of the three evaluated plant species when compared to bare soil. Speed of germination ranged between 3.5 and 5 days and there were no differences between substrates.
\end{abstract}

Keywords: Endocarpon pusillum, northeastern Mexico, Nostoc commune, Placidium, semiarid grasslands.

Resumen: En los pastizales semiáridos del noreste de México se encuentran plantas y animales endémicos, y son un refugio importante para animales residentes y migratorios. Aquí, como en otras zonas semiáridas, las costras biológicas del suelo son un componente clave del ecosistema. Sin embargo, los reportes sobre su efecto en la germinación de plantas vasculares son contrastantes. En este trabajo se investiga si la germinación de algunas especies de plantas nativas sería inhibida por la presencia de costras biológicas del suelo como se ha encontrado en otros estudios, y se evalúa el efecto de cinco líquenes (Endocarpon pusillum Hedw., Placidium sp., Psora cerebriformis W.A.Weber, Psora decipiens (Hedw.) Hoffm., Xanthoparmelia chlorochroa (Tuck.) Hale), una cianobacteria (Nostoc commune Vauch.) y una hepática (Oxymitra sp.), que son componentes de las costras biológicas del suelo dominantes en el área. Los efectos evaluados son en el porcentaje (germinabilidad) y rapidez de germinación $\left(\mathrm{t}_{50}\right)$ de tres especies de plantas nativas del área: Frankenia gypsophila I.M.Johnst., Muhlenbergia arenicola Buckl. y Sartwellia mexicana A.Gray. Las pruebas de germinación se realizaron en una cámara ambiental a $26^{\circ} \mathrm{C}$, humedad constante del $60 \%$, $12: 12$ horas luz: oscuridad. Las costras biológicas no afectaron el porcentaje de germinación de las tres especies de plantas evaluadas comparado con el suelo desnudo. La rapidez de germinación estuvo entre 3.5 y 5 días, sin diferencias entre los sustratos.

Palabras clave: Endocarpon pusillum, noreste de México, Nostoc commune, pastizales semiáridos, Placidium.

B iological soil crusts (BSC) are communities of organis$\mathrm{ms}$ that live in the soils of arid and semiarid areas, and are the main living cover in many arid areas of the world (Belnap, 2006). BSC communities consist of soil surfacedwelling cyanobacteria, green algae, microfungi, bacteria, lichens, and bryophytes (Hawkes, 2003; Zhang, 2005; López-Cortés et al., 2010) that grow on top or within the top layers of soil (Belnap et al., 2001; Quiñones-Vera et al.,
2009). They influence local hydrological cycles, including soil porosity, roughness, aggregate stability, texture, pore formation, and water retention (Belnap, 2006), contribute to soil retention (Belnap and Gardner, 1993; Zhang et al., 2006), and facilitate the accumulation of soil nutrients (Jafari et al., 2004). Due to the effects of microtopography, and water and nutrients fluxes, BSC affect the distribution of resources in the soil, contributing to vegetation cluster patterns 
(Deines et al., 2007) and probably improve water infiltration and retention in the soil (Casenave and Valentin, 1989; Montaña et al., 1995; Rosentreter and Belnap, 2001; ReyesGómez et al., 2007; Yair, 2008; Chamizo et al., 2010).

BSC can also affect the establishment and survival of vascular plants, and available data show varied results for BSC. Studies have shown BSC having either facilitative, inhibitory or no effect on vascular plant establishment and cover (During and Van Tooren, 1990; Belnap et al., 2001). Existing evidence suggests that the effects of crusts on seed germination vary depending on the soil crust composition and plant characteristics (Lesica and Shelly, 1992; Zaady et al., 1997; Prasse and Bornkamm, 2000; Rivera-Aguilar et al., 2005; Serpe et al., 2006; Deines et al., 2007), as seeds vary in their germination requirements and consequently may respond differently to the conditions created by the crust (Baskin and Baskin, 1998). Positive effects of the crust on vascular plants may be the result of improved soil moisture conditions and nutrient availability, as well as a decrease in predation (During and Van Tooren, 1990; Belnap and Harper, 1995). Negative effects could be attributed to competition for water and nitrate, changes in the red/farred ratio or the presence of inhibitory compounds (During and Van Tooren, 1990; Callaway and Walker, 1997).

Speed of germination results for different BSC and plant species have also been controversial. For example, Godínez-Alvarez et al. (2012) found no differences in $\mathrm{t}_{50}$ for Agave marmorata Roezl. and Neobuxbaumia tetetzo (F.A.C.Weber) Backeb. germinated on a cyanobacteria crust and on bare soil. Deines et al. (2007) compared germination of two grass species (Bromus tectorum L. and Vulpia microstachys (Nutt.) Benth.) on three different substrates (lichen crust, mixed crust, and bare soil) and found a longer germination time on the lichen crust than on bare soil and no differences between the mixed crust and bare soil for both grass species.

Recent studies have demonstrated that BSC dominated by Diploschistes sp. reduced plant emergence (Escudero et al., 2007; Serpe et al., 2008). This might be due to the sealing of the soil pores by these crusts that might reduce water availability and thus inhibit germination (Eldridge et al., 2010). Similarly, Prasse and Bornkamm (2000) in the Negev Desert in Israel and Li et al. (2005) in the Tengger Desert of China found greater seedling emergence after removal or destruction of the BSC. St. Clair et al. (1984) observed significantly higher germination for three grass species on algal crusts compared with mixed crusts of lichens, mosses and algae. Zamfir (2000) showed that seedling emergence was much lower on lichen mats compared with moss mats for three of the four species studied.

These uneven results highlight the relevance of evaluating more specific associations of BSC and vascular plant species in order to assess seed germination, seedling emergence, and plant establishment. Hence, in this study we determined the effect of seven dominant BSC from the Northern Mexican Plateau (Molina-Guerra, 2013) on the germination percentage and speed of germination $\left(t_{50}\right)$ of three native plants. While the physical barrier of crusts is likely to affect soil moisture and several stages of seedling growth, in here we asked whether germination would be inhibited by the presence of lichens as it has been found in other studies (Deines et al., 2007).

\section{Material and methods}

Study area. The BSC were collected in the states of Nuevo León, Coahuila, and San Luis Potosí within the Southern part of the Chihuahuan Desert in northeastern Mexico. The collection area was within $25^{\circ} 13^{\prime} 51^{\prime \prime} \mathrm{N}$ and $101^{\circ} 17^{\prime} 28^{\prime \prime}$ $\mathrm{W}$. Mean annual temperature for the region is $17.2^{\circ} \mathrm{C}$, with a minimum of $-1.8{ }^{\circ} \mathrm{C}$ in January and maximum of $35.1{ }^{\circ} \mathrm{C}$ in May. Average annual rainfall is $386.43 \mathrm{~mm}$, with March being the driest month $(8.43 \mathrm{~mm})$ and August being the wettest (58.06 mm; SMN, 2000).

According to the Lof P. and van Baren (1987; FAOUNESCO classification), soils in the area are mainly solonchack and calcaric phaeozem, and smaller areas of chromic vertisol and luvic chernozem (INEGI, 1981a, b; 2002). These soils have been classified into three broad groups: (1) those with a high content of calcium carbonate and no gypsum; (2) soils with similar contents of gypsum and calcium carbonate; and (3) those with high gypsum content and very little or no calcium carbonate (Pando et al., 2013). Sampling areas are between 1,800 and $2,000 \mathrm{~m}$ altitude.

The vegetation is mainly made from communities of halophytic/gypsophyllus grasslands associated with microphyll and rosetophyll desert scrub (Estrada-Castillón et al., 2010), where the most abundant plant families are: Poaceae, Chenopodiaceae, and Frankeniaceae (Rzedowski, 1978). These grasslands contain several endemic plants (Dalea gypsophila, D. radicans, Frankenia gypsophila, Machaeranthera heterophylla, and M. crutchfi eldii; Estrada-Castillón et al., 2010), and animals (Cynomys mexicanus, Spizella wortheni; Baillie and Groombridge, 1996).

Field sampling. The dominant BSC were collected with a cylinder designed by the authors. The size of the cylinder was adjusted to the size of the Petri dishes where the samples were placed $(100 \times 15 \mathrm{~mm})$. All Petri dishes were covered with mixed crust where at least $50 \%$ was occupied by the treatment species. Samples to be collected were previously sprayed with distilled water to facilitate their extraction. The cylinder was placed on top of the soil and pressed until the lower part of the cylinder touched the soil crust. Once the crust was extracted it was placed on a Petri dish and sealed with tape. The components of the collected mixed crusts were identified by experts from two mycology laboratories, there were: five lichens Endocarpon pusillum, Verrucaria- 
ceae; Placidium sp., Verrucariaceae; Psora cerebriformis, Psoraceae; Psora decipiens, Psoraceae; and Xanthoparmelia chlorochroa, Parmeliaceae (all squamulose except $X$. chlorochroa which is usually foliose); one cyanobacteria: Nostoc commune, Nostocaceae; and one hepatic: Oxymitra sp., Oxymitraceae. Additionally, samples of bare soil from the three broad groups of soils in the region were collected to be used as controls.

Three native plant species that co-exist with the BSC were also selected and their seeds obtained: Frankenia gypsophila I.M.Johnst., Frankeniaceae; Muhlenbergia arenicola Buckl., Poaceae; and Sartwellia mexicana A.Gray, Asteraceae. Seeds of the first two plant species have been found to have a high germination percentage ( $>80 \%)$ under laboratory conditions, using agar as a medium (Contreras et al., 2012). The seeds were collected in September 2011 from plants growing within the study region; each seed lot contained a minimum of 50 individuals. The seeds were manually extracted, cleaned and selected using a stereoscopic microscope. They were then stored in plastic containers at room temperature.

There were no pre-treatments for either the seeds or the BSC before germination tests. Germination tests were carried out in an environmental chamber (Lumistell ${ }^{\mathrm{MR}}$ ICP-54) at $26^{\circ} \mathrm{C}$ (following Contreras et al., 2012) and at a constant humidity of $60 \%$ with $12: 12 \mathrm{~h}$ light and darkness. The seeds were checked every $24 \mathrm{~h}$ (Baskin and Baskin, 1998) over one month. Light intervals were defined to resemble average day and night number of hours for these latitudes. Temperature was established according to Contreras et al. (2012), who worked on germination of these plant species even though her work did not involve soil biological crusts.

Experiment set up and analysis. There were 30 treatments arranged randomly in the germination chamber (ten substrates (BSC or soil) $\times$ three plant species) with five replicates. The substrates were: S1: soil with gypsum and calcium carbonate (Sgc) (45\% gypsum and 35\% calcium carbonate); S2: Psora cerebriformis; S3: Placidium sp.; S4: Endocarpon pusillum; S5: Nostoc commune; S6: soil with calcium carbonate and no gypsum (Sc) (0\% gypsum and 62\% calcium carbonate); S7: soil with gypsum and no calcium carbonate $(\mathrm{Sg})$ (50\% gypsum and 5\% calcium carbonate); $\mathrm{S} 8$ : Xanthoparmelia chlorochroa; S9: Psora decipiens; and S10: Oxymitra sp. Seeds were from three plant species: Frankenia gypsophila, Muhlenbergia arenicola, and Sartwellia mexicana. The substrates S2-S5, as well as S8-S10 were labeled with the name of the species occupying at least $50 \%$ of the Petri dish.

Ten seeds of each plant species were sown on the surface of the dominant BSC in each Petri dish (50 seeds per treatment). The seeds were sown evenly spaced on the surface of the selected species of BSC, except for those on bare soil treatment. For samples not covering $100 \%$ of the surface, seeds were specifically placed on top of the particular soil crust component. Germination was recorded when the seed radicle emerged and was visible (Jurado and Westoby, 1992; Welbaum et al., 1998). From these observations we obtained; (1) germinability, calculated as the percentage of germinated seeds at the end of the experiment (Flores and Jurado, 1998; Flores and Briones, 2001); and (2) Speed of germination or half-time of germination $\left(\mathrm{t}_{50}\right)$, calculated as the time (in days) at which $50 \%$ of the seeds germinated (Grime et al., 1981; Thompson and Grime, 1983; Jurado and Westoby, 1992; Flores and Jurado, 1998; Flores and Briones, 2001; Pérez-Sánchez et al., 2011).

Variance was tested for normality and homogeneity and then ANOVA tests were performed. Mean comparisons were carried out using Tukey test $(\alpha=0.05)$ for Muhlenbergia arenicola that showed homogeneity of variances $(\mathrm{W}=0.553)$ and Games-Howell $(\alpha=0.05)$ for Frankenia gypsophila that did not have homogeneous variances (W $<0.0001)$. Games-Howell test does better than the Tukey HSD if variances are unequal or if the number of replicates is fewer than five (Sileshi, 2012). All analysis were performed using SPSS statistics package ver. 19 (MX19000242) looking for differences in germination percentage between substrates for each plant species.

Speed of germination or half-time of germination $\left(t_{50}\right)$ was also analyzed and species were classified according to Jurado and Westoby (1992) into three categories: (1) fast (50\% germination in 1-4 days), (2) moderate $(50 \%$ germination in 4-7 days), and (3) slow (50\% germination in 7-9 days or longer). Differences in $t_{50}$ were analyzed by ANOVA and Tukey test, and included only those Petri dishes where at least one seed had germinated.

\section{Results}

Germination percentage. As a whole, there were no significant differences in germinability between substrates $(\mathrm{F}=$ 1.09 , df $=9, P=0.368$ ). Germinability differed between substrates for Frankenia gypsophila $(\mathrm{F}=3.712, \mathrm{df}=49, P=$ $0.002)$ and Muhlenbergia arenicola $(\mathrm{F}=3.094, \mathrm{df}=49, P$ $=0.007)$, and there were no differences for Sartwellia mexicana $(\mathrm{F}=1.650, \mathrm{df}=49, P=1.34)$. Frankenia gypsophila germinability was similar in all but one substrate: Nostoc commune where germinability was lower than in the others (66\%; Table 1). The lowest germinability of Muhlenbergia arenicola was on bare soil with gypsum (18\%), there were no differences between the other substrates.

Frankenia gypsophila showed the highest germination percentage ( $91.4 \% \pm 13 \mathrm{sd}$ ), followed by Muhlenbergia arenicola $(56.6 \% \pm 17 \mathrm{sd})$ and Sartwellia mexicana $(13 \% \pm 9$ sd). This ranking was consistent when evaluating germination percentage by substrate, except for Nostoc commune where $M$. arenicola had a higher germination percentage (78\%) than F. gypsophila (66\%). 
Speed of germination or half-time of germination $\left(t_{50}\right)$. The $\mathrm{t}_{50}$ was analyzed only for those seed species whose seed germination percentage was above $15 \%$ in all substrates. This threshold was established because germination percentages below $15 \%$ could generate $t_{50}$ values that did not represent the species speed of germination, but rather reflected that those seeds might require other treatments to promote germination. Hence, $t_{50}$ is not shown for Sartwellia mexicana seeds.

Frankenia gypsophila and Muhlenbergia arenicola seed germination started on the second day after sowing and had an average $\mathrm{t}_{50}$ of 4.86 and 3.65 days, respectively. According to Jurado and Westoby (1992), germination for M. arenicola was fast, and moderate for $F$. gypsophila across substrates. Speed of germination $\left(\mathrm{t}_{50}\right)$ was equal for all substrates $(\mathrm{F}=$ $1.66, \mathrm{df}=9, P=0.109)$ and their values ranged between 3.5 and 5 days (Table 1).

\section{Discussion}

Germination percentage or germinability. Results from this research indicated that, under laboratory conditions, the BSC did not affect the seed germination percentage of the three evaluated plant species from the Northern Mexican Plateau.

In agreement with this study's findings, Li et al. (2005) found no differences in germination percentage and seedling establishment between soils with biological crusts and bare soil for Eragrostis poaeoides Beauv. and Bassia dasyphylla O.Kuntze under wet conditions in the Tengger Desert in Northern China. Deines et al. (2007) found negative effects for BSC on the germination of Bromus tectorum L. and
Vulpia microstachys Nutt., where germination percentage, analyzed under laboratory conditions, was about three times lower on the BSC dominated by the lichen Diploschistes muscorum (Scop.) R.Sant, than on bare soil. Germination on bare soil was found to be equal to mixed biological crusts which contain the lichens Aspicilia, Caloplaca, Candelariella, Collema, and Placidium, the cyanobacterium Microcoleus, and a low growing form of the moss Syntrichia caninervis Mitt. Zaady et al. (1997) found that germination of three mucilaginous seeds decreased on soils with a smooth crust dominated by cyanobacteria.

The effects of the BSC on germination may vary according to plant species, the type of biological crust (either smooth or rough), and the species that dominate in the crust (Rivera-Aguilar et al., 2005; Deines et al., 2007), as well as the size and morphology of the seeds and the presence of microsites in the crust suitable for germination ( $\mathrm{Li}$ et al., 2005). Escudero et al. (2007) and Serpe et al. (2008) showed that BSC reduced seedling emergence when it was dominated by species like Diploschistes sp., because this lichen might seal the soil, thus reducing water availability during the germination period of some plants (Otsus and Zoel, 2004; Morgan, 2006). Contrastingly, the presence of both algal and moss crusts significantly enhanced the germination of Bassia dasyphylla (Fisch. \& Mey.) O.Kuntze and Artemisia ordosica Krasch. compared with uncrusted soil (Su et al., 2009).

Godínez-Alvarez et al. (2012) found that biological soil crusts increased germination of one species (Agave marmorata) but did not show any effect on the germination of two other species from the same region (Prosopis laevigata $(\mathrm{H}$. $\&$ B.) Jonhst. and Neobuxbaumia tetetzo). Germination of

Table 1. Germination percentage and speed of germination $\left(t_{50}\right)$ (average and standard error, $\mathrm{n}=5$ ) per plant species by substrate.

\begin{tabular}{|c|c|c|c|c|c|c|c|c|}
\hline \multirow[t]{2}{*}{ Substrate } & \multicolumn{2}{|c|}{ Frankenia gypsophila } & \multicolumn{2}{|c|}{ Muhlenbergia arenicola } & \multicolumn{2}{|c|}{ Sartwellia mexicana } & \multicolumn{2}{|c|}{$\mathrm{t}_{50}$} \\
\hline & $\%$ & S.E. & $\%$ & S.E. & $\%$ & S.E. & $\%$ & S.E. \\
\hline $\begin{array}{l}\text { Bare soil with gypsum and } \\
\text { calcium carbonate }\end{array}$ & 100 & 0.00 & 60 & 7.07 & 10 & 5.47 & 56.7 & 4.0 \\
\hline Psora cerebriformis W.A.Weber & 90 & 4.47 & 48 & 11.14 & 10 & 3.16 & 49.3 & 4.7 \\
\hline Placidium sp. & 98 & 2.00 & 52 & 11.58 & 0 & 0.00 & 50.0 & 3.6 \\
\hline Endocarpom pussillum Hedwig & 100 & 0.00 & 70 & 3.16 & 2 & 2.00 & 57.3 & 3.5 \\
\hline Nostoc commune Vauch. & 66 & 11.66 & 78 & 10.20 & 14 & 5.10 & 52.7 & 4.9 \\
\hline Bare soil with gypsum & 96 & 4.00 & 18 & 5.83 & 30 & 16.43 & 48.0 & 4.7 \\
\hline $\begin{array}{l}\text { Xanthoparmelia chlorochroa } \\
\text { (Tuck.) Hale }\end{array}$ & 70 & 15.81 & 54 & 9.27 & 20 & 5.48 & 48.0 & 5.0 \\
\hline Oxymitra sp. & 96 & 2.45 & 70 & 8.94 & 14 & 5.10 & 60.0 & 4.1 \\
\hline Bare soil with calcium carbonate & 100 & 0.00 & 54 & 14.35 & 12 & 5.83 & 55.3 & 3.6 \\
\hline Psora decipiens (Hedwig) Hoffm. & 98 & 2.00 & 62 & 7.35 & 18 & 4.90 & 59.3 & 4.1 \\
\hline
\end{tabular}


A. marmorata was significantly higher on a cyanobacteria crust $(72.5 \%)$ than on a mixed crust $(30 \%)$ that contained cyanobacteria and moss (mainly Bryum and Pseudocrossidium species). Germination on bare soil (52.5\%) had intermediate values that did not differ significantly from any of the BSC treatments. Godínez-Alvarez et al. experiment was also conducted in a laboratory and at constant humidity for all treatments. Zhang et al. (2010) found contrasting results using moist and dry conditions for five species in the China Gurbantunggut Desert, the presence of BSC resulted in less seeds germinating in two out of five species under dry conditions, and in three out of five species under moist conditions.

Speed of germination $\left(t_{50}\right)$. Seeds of Muhlenbergia arenicola and Frankenia gypsophila showed average $\mathrm{t}_{50}$ of 3.65 days (fast) and 4.86 days (moderate), respectively. These short germination times could reflect the response of the seeds to one single event of profuse rainfall, typical for an environment where wet soils are uncommon and humid periods are brief (Jurado and Westoby, 1992), which are typical climatic characteristics for the area where the seeds chosen for this study came from.

Speed of germination was similar across substrates. Likewise, Godínez-Alvarez et al. (2012) found that the number of days to $50 \%$ of the total germination $\left(\mathrm{t}_{50}\right)$ for Agave marmorata and Neobuxbaumia tetetzo, from semiarid Valle de Tehuacan in Mexico, were between 1.88 and 5.5 days for the different species and treatments with no statistical differences between them. In contrast, in the same area of Valle de Tehuacan in Mexico, Rivera-Aguilar et al. (2005) evaluated seed germination rate using quadratic regressions for two native plant species (Mimosa luisana Brandegee and Myrtillocactus geometrizans (Martius) Console) concluded that seeds placed in BSC had a faster germination rate compared to those placed in bare soil. Contrarily, Deines et al. (2007) found that mean germination time (MGT) of Vulpia microstachys Nutt. and Bromus tectorum L. was faster on mixed crusts and on bare soil than on crusts of lichens, with an average of 5-7 days for the first two conditions, and 11 days for the crust of lichens. Also working with grasses (Festuca idahoensis Elmer, Festuca ovina L., Elymus wawawaiensis J. Carlson \& Barkworth, and Bromus tectorum L.), Serpe et al. (2006) found that MGT was shorter for seeds germinating on bare soil than on BSC made of short or large mosses (Tortula ruralis Hedw. and Bryum argenteum Hedw.), and Briggs and Morgan (2011) found that two out (Salvia verbenaca and Vittadinia gracilis) of the five species tested, exhibited shorter $\mathrm{t}_{50}$ on disturbed soil crust than on moss and foliose lichen. The other species tested were Austrodanthonia sp. (Poaceae), Maireana excavata (Chenopodiaceae), and Leptorhynchos scaber (Asteraceae), all common in the semi-arid woodlands to the northwest of Melbourne, Australia.
These somehow uneven results on speed of germination $\left(\mathrm{t}_{50}\right)$ seem to be a consequence of differences on the way the experiments were carried out (e.g. providing or not constant humidity), as well as the roughness of the evaluated BSC and the dominant species on the crust.

Further experimental and field evidence is required to better understand the implications of BSC on seed germination and seedling establishment.

\section{Conclusions}

The purpose of this paper was to assess whether the more conspicuous types of BSC found in the semiarid grasslands of northeastern Mexico inhibit or delay seed germination of vascular plants as has been reported for other biological soil crusts. By analyzing the effect of five lichens, one cyanobacteria, and one hepatic on the germination of native plants, we conclude that under high substrate humidity conditions, BSC did not inhibit or delay seed germination of the vascular plants used for this study.

Muhlenbergia arenicola and Frankenia gypsophila had fast and moderate average speed of germination or half-time of germination $\left(t_{50}\right)$ of 3.65 days and 4.86 days, respectively, according to the expected germination times in environments where there are only brief periods of high soil humidity. Values for $\mathrm{t}_{50}$ were between 3.5 and 5 days and did not differ between substrates.

\section{Acknowledgements}

This work was funded by the PRACTICE (Grant No. 226818) and UANL PAICYT (No. CN-064-09) projects.

\section{Literature cited}

Baillie J. and Groombridge B. 1996. IUCN Red list of threatened animals. The IUCN Species Survival Commission, Gland.

Baskin C.C. and Baskin J.M. 1998. Seeds: Ecology, Biogeography, and Evolution of Dormancy and Germination. Academic Press, San Diego.

Belnap J. 2006. The potential roles of biological soil crusts in dryland hydrologic cycles. Hydrological Process 20:31593178.

Belnap J. and Gardner J.S. 1993. Soil microstructure in soils of the Colorado Plateau: The role of the cyanobacterium Microcoleus vaginatus. Great Basin Naturalist 53:40-47.

Belnap J. and Harper K.T. 1995. Influence of cryptobiotic soil crust on elemental content of tissue in two desert seed plants. Arid Soil Research and Rehabilitation 9:107-115.

Belnap J., Büdel B. and Lange O.L. 2001. Biological soil crusts: characteristics and distribution. In: Belnap J. and Lange O.L. Eds. Biological Soil Crusts: Structure, Function and Management, pp. 3-30, Springer-Verlag, Berlin.

Briggs A.L. and Morgan J.W. 2011. Seed characteristics and soil surface patch type interact to affect germination of semi-arid woodland species. Plant Ecology 212:91-103. 
Callaway R.M. and Walker L.R. 1997. Competition and facilitation: a synthetic approach to interactions in plant communities. Ecology 78:1958-1965.

Casenave A. and Valentin C. 1989. Les États de Surface de la Zone Sahélienne. Influece sur l'infiltration. Editions de l'ORSTOM. Institut Français de Recherche Scientifique pour le Développement en Coopération, Paris.

Chamizo S., Rodríguez-Caballero E., Miralles-Mellado I., Afana A., Lázaro R., Domingo F., Calvo-Cases A., Sole-Benet A. and Cantón Y. 2010. Características de las costras físicas y biológicas del suelo con mayor influencia sobre la infiltración y la erosión en ecosistemas semiáridos. Pirineos 165:69-96.

Contreras Q.M., Pando M., Estrada E., Jurado E. and Flores J. 2012. Germinación de semillas de especies nativas de los pastizales semiáridos del altiplano mexicano. VIII Simposio Internacional sobre la Flora Silvestre en Zonas Áridas. Universidad Autónoma Chapingo. Unidad Regional Universitaria de Zonas Áridas, Gómez Palacio, Durango, México.

Deines L., Rosentreter R., Eldridge D.J. and Serpe M.D. 2007. Germination and seedling establishment of two annual grasses on lichen-dominated biological soil crusts. Plant and Soil 295:23-35.

During H.J. and Van Tooren B.F. 1990. Bryophyte interactions with other plants. Botanical Journal of the Linnean Society 104:79-98.

Eldridge D.J., Bowker M.A., Maestre F.T., Alonso P., Mau R.L., Papadopolous J. and Escudero A. 2010. Interactive effects of three ecosystem engineers on infiltration in a semi-arid Mediterranean grassland. Ecosystems 13:499-510.

Escudero A., Martínez I., de la Cruz A., Otálora M.A.G. and Maestre F.T. 2007. Soil lichens have species-specific effects on the seedling emergence of three gypsophile plant species. Journal of Arid Environments 70:18-28.

Estrada-Castillón E., Scott-Morales L., Villarreal-Quintanilla J.A., Jurado-Ybarra E., Cotera-Correa M., Cantú-Ayala C. and García-Pérez J. 2010. Clasificación de los pastizales halófilos del noreste de México asociados con perrito de las praderas $(C y$ nomys mexicanus): diversidad y endemismo de especies. Revista Mexicana de Biodiversidad 81:401-416.

Flores J. and Briones O. 2001. Plant life form and germination in a Mexican inter tropical desert: effects of soil water potential and temperature. Journal of Arid Environments 47: 485-497.

Flores J. and Jurado E. 1998. Germination and early growth traits of 14 plant species native to northern Mexico. Southwestern Naturalist 43: 40-46.

Godínez-Alvarez H., Morín C. and Rivera-Aguilar V. 2012. Germination, survival and growth of three vascular plants on biological soil crusts from a Mexican tropical desert. Plant Biology 14:157-162.

Hawkes C.V. 2003. Microorganismos del suelo, plantas en peligro de extinción y la conservación del matorral de Florida. Ecosistemas 12:1-6.

INEGI. Instituto Nacional de Estadística y Geografía. 1981a. Sintesis Geográfica de Nuevo León. México, D.F.

INEGI. Instituto Nacional de Estadística y Geografía. 1981b. Síntesis Geográfica de Coahuila. México, D.F.

INEGI. Instituto Nacional de Estadística y Geografía. 2002. Síntesis de Información Geográfica del estado de San Luis Potosí. México, D.F.

Jafari M., Tavili A., Zargham N., Heshmati Gh.A., Zare C.M.A,
Shirzadian S., Azarnivand H., Zehtabian Gh.R. and Sohrabi M. 2004. Comparing some properties of crusted and uncrusted soils in Alagol Region of Iran. Pakistan Journal of Nutrition 3:273-277.

Jurado E. and Westoby M. 1992. Germination biology of selected central Australian plants. Australian Journal of Ecology 17:341-348.

Lesica P. and Shelly J.S. 1992. Effects of cryptogamic soil crust on the population dynamics of Arabis fecunda (Brassicaceae). American Midland Naturalist 128:53-60.

Li X.R., Jia X.H., Long L.Q. and Zerbe S. 2005. Effects of biological soil crusts on seed bank, germination and establishment of two annual plant species in the Tengger Desert (N China). Plant and Soil 277:375-385.

Lof P. and van Baren J. Comps. 1987. Soils of the World. International Soil Reference and Information Centre, FAO, UNESCO. Elsevier Science Publishing Co, Inc. Amsterdam.

López-Cortés A., Maya Y. and García-Maldonado J.Q. 2010. Diversidad filogenética de especies de Microcoleus de costras biológicas de suelo de la península de Baja California, México. Revista Mexicana de Biodiversidad 81:1-7.

Molina-Guerra V.M. 2013. Costras biológicas del suelo en ecosistemas de pastizales del altiplano del norte de México. Tesis doctoral. Facultad de Ciencias Forestales, Universidad Autónoma de Nuevo León. Linares. 129 pp.

Montaña C., Cavagnaro B. and Briones O. 1995. Soil water use by co-existing shrubs and grasses in the Southern Chihuahuan Desert, Mexico. Journal of Arid Environments 31:1-13.

Morgan J.W. 2006. Bryophyte mats inhibit germination of nonnative species in burnt temperate native grassland remnants. Biological Invasions 8:159-168.

Otsus M. and Zoel M. 2004. Moisture conditions and the presence of bryophytes determine fescue species abundance in a dry calcareous grassland. Oecologia 138:293-299.

Pando M.M., Reyna L., Scott L., and Jurado E. 2013. Caracterización del suelo en colonias de Cynomys mexicanus Merriam, 1892 en el noroeste de México. Revista Mexicana de Ciencias Forestales 4:98-105.

Pérez-Sánchez R.M, Jurado E., Chapa-Vargas L. and Flores J. 2011. Seed germination of Southern Chihuahuan Desert plants in response to elevated temperatures. Journal of Arid Environments 75: 978-980.

Prasse R. and Bornkamm R. 2000. Effect of microbiotic soil surface crusts on emergence of vascular plants. Plant Ecology 150:65-75.

Quiñones-Vera J.J., Castellanos-Pérez E., Valencia-Castro C.M., Martínez-Rubio J.J., Sánchez-Olvera T. and Montes-González C.A. 2009. Efecto de la costra biológica sobre la infiltración de agua en un pastizal. Terra Latinoamericana 27:287-293.

Reyes-Gómez V.M., Viramontes-Pereida D., Miranda-Ojeda N.E., Sánchez-Fernández P.B. and Viramontes-Olivas O.A. 2007. Papel hidrológico-ambiental de las propiedades hidráulicas del suelo superficial de la cuenca del río Conchos. Ingeniería Hidráulica en México 22:33-46.

Rivera-Aguilar V., Godínez-Alvarez H., Manuell-Cacheux I. and Rodríguez-Zaragoza S. 2005. Physical effects of biological soil crusts on seed germination of two desert plants under laboratory conditions. Journal of Arid Environments 63:344-352.

Rosentreter R. and Belnap J. 2001. Biological soil crusts of North America. In: Belnap J. and Lange O.L. Eds. Biological Soil 
Crusts: Structure, Function and Management, pp. 31-50. Springer-Verlag, Berlin.

Rzedowski J. 1978. Vegetación de México. Limusa, México, D.F.

Serpe M.D., Orm J.M., Barkes T. and Rosentreter R. 2006. Germination and seed water status of four grasses on moss-dominated biological soil crusts from arid lands. Plant Ecology 185:163178.

Serpe M.D., Zimmerman S.J., Deines L. and Rosentreter R. 2008. Seed water status and root tip characteristics of two annual grasses on lichen-dominated biological soil crusts. Plant and Soil 303:191-205.

Sileshi G.W. 2012. A critique of current trends in the statistical analysis of seed germination and viability data. Seed Science Research 22:145-159.

SMN. Servicio Meteorológico Nacional. 2000. Normales Climatológicas 1971-2000. <http://smn.cna.gob.mx/climatologia/ normales/estacion/nl/NORMAL19035.TXT> (consultado 8 de octubre de 2012).

St. Clair L.L., Webb B.L., Johansen J.R. and Nebeker G.T. 1984. Cryptogamic soil crusts: enhancement of seedling establishment in disturbed and undisturbed areas. Reclamation and Revegetation Research 3:129-136.

Su Y.G., Li X.R., Zheng J.G. and Huang G. 2009. The effect of biological soil crusts of different successional stages and conditions on the germination of seeds of three desert plants. Journal of Arid Environments 73:931-936.

Welbaum G.E., Bradford K.J., Yim K.O., Booth D.T. and Oluo- ch M.O. 1998. Biophysical, physiological and biochemical processes regulating seed germination. Seed Science Research 8: $161-172$.

Yair A. 2008. Effects of surface runoff and subsurface flow on the spatial variability of water resources in longitudinal dunes. In: Breckle S.W., Yair A. and Veste M. Eds. Arid Dune Ecosystems: The Nizzana Sands in the Negev Desert, pp. 251-269. Springer, Berlin.

Zaady E., Gutterman Y. and Boeken B. 1997. The germination of mucilaginous seeds of $\mathrm{t}$ Plantago coronopus, Reboudia pinnata and $\underline{\mathrm{t}}$ Carrichtera annua on cyanobacterial soil crust from the Negev Desert. Plant and Soil 190:247-252.

Zamfir M. 2000. Effects of bryophytes and lichens on seedling emergence of alvar plants: evidence from greenhouse experiments. Oikos 88:603-611.

Zhang Y. 2005. The microstructure and formation of biological soil crusts in their early developmental stage. Chinese Science Bulletin 50:117-121.

Zhang Y.M., Wu N., Zhang B.C. and Zhang J. 2010. Species composition, distribution patterns and biological functions of biological soil crusts in the Gurbantunggut Desert. Journal of Arid Land 2:180-189.

Zhang Y.M., Wang H.L., Wang X.Q., Yang W.K. and Zhang D.Y. 2006. The microstructure of microbiotic crust and its influence on wind erosion for a sandy soil surface in the Gurbantunggut Desert of Northwestern China. Geoderma 132:441-449.

Received: April 8th, 2013

Accepted: July 7th, 2013 